\title{
Mainstreaming sustainability science to enhance the impacts of "Tridharma" in higher education institution: IPB lessons learned and future direction
}

\author{
Arif Satria and Aceng Hidayat \\ Rector, Bogor Agricultural University (IPB), Kampus IPB Darmaga, Bogor 16680, Indonesia
}

\begin{abstract}
The adoption of transdisciplinary approaches to address complexity and uncertainty of the problems has been recommended to formulate the effective solution. Although scientists have been working towards the direction, there have been still little integration on policy and concerted implementation to deal particularly with cross-cutting issues on food security, sustainable agriculture, renewable energy and other green development issues. Bogor Agricultural University (IPB) has recently adopted the concept of transdisciplinary and sustainability sciences to better integrate and utilize available resources and management strategies as stated in IPB's Long-term Plan and in recent policy to establish Center for Transdisciplinary and Sustainability Sciences (IPB-CTSS). The drivers for this policy are actually the already established research, academic and community service consortia in which students, scientists, practitioners and policy makers have been working interdisciplinary towards effective solution for achieving better impacts of IPB Tridharma activities. We will discuss the lessons learned, challenges and opportunities identified as solid foundation to implement the concept for enhancing the better impacts of universities extended obligatory tasks on education, research, community services, innovation and business.
\end{abstract}

\section{Introduction}

In today's world, the development of higher education institution (HEI) is facing more complex problems associated with uncertainties that are requiring new solutions. Based on CCAP (2017), there are practically seven biggest problems the nation faces with respect to its universities' development, including the huge increase in the cost of universities [1]. On the other hand, universities are expected to contribute more actively in addressing nations problems that requires a new approach due to the complexity of the problems. Sustaining our national development requires knowledge that is adaptive to the problems, particularly for IPB Trdidharma activities, such as sustainability issues on agriculture, renewable energy and other land and marine based sector development. Gaps in the implementation are identified due to non-comprehensive approaches leading to the failure of the target achievement. In order to tackle those problems and to enhance the quality of Tridharma and its impacts, IPB has formulated an IPB Future vision with the aim to enhance and to support the nation's dignity. The vision of IPB towards 2045 can be stated as "To be a leading university in strengthening the nation dignity through globally excellent higher education on tropical agriculture, marine and biosciences".

IPB is coming up with a specialized strategy through the implementation of transdisciplinary and sustainability concepts that has been described many authors among other by Burger and Kamber (2003) where the approaches are consisted of 3 (three) parts, which are problem integration, research integration and solution integration [2]. These parts are made to form a solution to better solve particular problems that come along the way in the middle of the university's development. Problem integration includes the process of describing the problems which may come from the issues on the environment and from the stakeholders. The problems that have been defined in the first phase then will be taken into consideration on the second phase, which is research integration. In research integration, the university with the help of each faculties has to determine research questions, the research itself and research results. In this matter, the university has to build a strong relation and connection between all the disciplines in IPB and to take the multidisciplinary, interdisciplinary and even transdisciplinary approaches into account. The last phase is solution integration in which IPB creates solution based on the research results and to realize the solution using the method of scenario building. The outcome of these phases is to build a certified knowledge and establish creative pool of experts in order to strengthen the university's performance in a changing world. Down-streaming the result results into university business and innovation program has been defined as an additional important pillar to be integrated in the Tridharma business process [3]. 
Nowadays, IPB comprises 9 (nine) faculties for undergraduate program and 3 (three) schools. The 9 (nine) faculties are Agriculture, Veterinary Medicine, Fishery \& Marine Sciences, Animal Sciences, Forestry, Agricultural Engineering \& Technology, Mathematics \& Natural Sciences, Economics \& Management and Human Ecology. The 3 (three) schools are Graduate School, Business School and Vocational School. The total number of students who are pursuing their studies in IPB is around 22000 students which is consisted of 16856 undergraduate students and 5144 postgraduate students. In addition to this number is vocational students with a umber $\mathrm{f}$ around 6000 students. The university's effort in enhancing its education and its employment quality as well as its performance has been paid well and has been acknowledged by World University Rankings and UI Greenmetric. By 2017, IPB is ranked \#51 - 100 Top Universities by Subject Agriculture and Forestry by World University Rankings, is also ranked \#147 Top Universities by Asia University Rankings and ranked \#751 - 1000 Top World Universities by World University Rankings. Moreover, based on UI Greenmetric, IPB is now placed in number 52.

Through utilizing the current organizational capacity, attempts have been carried out to integrate all the resources and strategic management for resulting in better impacts of IPB's Tridharma activities. This paper aims shortly to describe the lessons learned and also challenges that IPB is facing in mainstreaming the sustainability sciences to enhance the impact of HEI's Tridarma activities.

\section{Global agenda and research priorities}

Building on the principle of "leaving no one behind", United Nations has formed the 2030 Agenda for Sustainable Development that includes 17 Sustainable Development Goals (SDGs). As a well-known higher education, IPB is determined to support the SDGs through innovation and research. IPB has put SDGs as its global agenda while developing its university's research agenda in various sectors. IPB has successfully produced Strategic Research Agenda in Food, Energy, Poverty, Ecology and Biomedicine that requires the transdisciplinary approaches.

IPB has recently established a Center for Transdisciplinary \& Sustainability Sciences (IPB CTSS) that will in the future be a knowledge hub of existing large research platforms including pool of experts. At the moment, the following examples of research consortia are expected to be integrated for better impacts of the results carried out by interdisciplinary research teams to address SDGs (sustainable development goals) related issues, as follows:

1. CRC990 - EFFoRTS with the emphasis on Ecology and Socio-economy and funded by CRC990 and the Ministry of Research, Technology and Higher Education of Indonesia - SDG No. 15
2. REDD+ with the emphasis on Reducing Emission from Deforestation \& Forest Degradation funded by DANIDA - SDG No. 13

3. Zoonoses with the emphasis on Health \& Biomedicine funded by JST/SATREPS and JICA SDG No. 3

4. Australia Indonesia Center (AIC) with the emphasis on Food/Agriculture \& Infrastructure funded by AIC and the Ministry of Research, Technology and Higher Education of Indonesia SDG No. 6

5. EMBRIO with the emphasis on Marine Biodiversity funded by IPB and the Ministry of Research, Technology and Higher Education of Indonesia SDG No. 14

6. LISAT with the emphasis on Remote Sensing/Satellite for Food Security and Environmental Monitoring funded by LAPAN, IPB and the Ministry of Research, Technology and Higher Education of Indonesia - SDG No 2

7. PETUAH with the emphasis on Green Knowledge Management, funded by MCA-I - SDG No. 17

8. Peat Fire with the emphasis on Environment \& Climate Change funded by NASA - SDG No. 13

9. Agri_Insurance with the emphasis on Food Security funded by JST/SATREPS and JICA - SDG No. 9

10. ANBIOCORE with the emphasis on Food Security \& Sovereignty funded by USAID - SHERA - SDG No. 2

In addition to research consortia, one of important IPB's infrastructures is IPB Science Park with the core focuses are Technology Transfer and Legal, Business Development, Capacity Building and pool of Expertise, Marketing and Promotion, and ICT. Each focus is dealing with different kind of tasks which will enhance the technology transfer flow with respect to business regulation, innovation support and regulation/incentive support from the government to the process of technology transfer for business (commercial) and for social/non-commercial purposes. IPB Science Park is a subsidiary company of PT BLST (Bogor Life Science and Technology), the Holding Company of IPB woth a main function to manage technology transfer for business purposes (commercial). The technology transfer from various sectors and various levels of company/society delivers its positive impact to social/extension in the form of community services managed by LPPM (Institute of Research and Community Services) and to commercial objectives in the form of business/revenue streams managed by BLST. Moreover, these actions will later on give impacts on economic development and prosperity.

\section{Lessons learned, challenges \& opportunities}

Economic development of the country can be enhanced by a more active participation of HEI/Universities by implementing the actionable knowledge proactively 
through the engagement of wide range of stakeholders. For instance, IPB has developed the new varieties of paddy with higher productivity compared to the previous variety which are called IPB 3S. This new type of paddy was developed by Dr. Hajrial Aswidinnoor initially in order to achieve Indonesia's rice sovereignty in collaboration with MoRTHE (KEMENRISTEKDIKTI), MoA (KEMENTAN), PT. BLST, seed association and farmer groups. Other commodities with positive impacts includes also papaya seed, chili seeds, agricultural machinery, biomedical products (e.g. enzymes, animal pharmaceutical producst etc.).

In addition, IPB is also developing outlets for IPB Products which are located on places around JABODETABEK, such as Botani Square (Bogor), Gandaria Cit (Jakarta), Mal Artha Gading (Jakarta), Kalibata City (Jakarta) and Mal Teras Kota BSD (Tangerang). The outlets are selling IPB's innovative products that are produced from research results (IPR base and non IPR) and from small and medium business enterprises fostered by IPB through community services. The products include food, beverages, fruits, herbal medicine, body care etc.

Due to a rapid change in the world, IPB has to come up with new solutions and innovations to deal with the opportunities, challenges and the future that the changing world brings. There is a growing interest on the nexus of food, health, energy, water and related issues with the SDGs. Therefore, the university has to increase human capacity and competency in conducting research and creating solutions to solve these issues. Moreover, government has also put forward the nation's priority to address issues on rural development, social forestry and renewable energy so that the wealth of the local people can be increased. In order to create a transdisciplinary and sustainability approaches, the important thing to be done by the university is integrating and managing the expertise, resources and the networks. These actions can lead the university to develop broader research possibilities with stakeholders, companies and even with international partner countries. Moreover, the results of the researches can only be real if they are implemented correctly in the society which means the university needs to link/connect scientific discovery to policies and practices through down-streaming processes, e.g. commercial and non-commercial purposes. IPB is on the steering wheel through the established IPB CTSS for future direction on the establishment of community practices (CoP) or forum to address the issues in sustainability.

\section{Closing remarks}

The research and innovation activities have become the hub/center for the start of mainstreaming sustainability in HEI's Tridharma activities. The pools of experts and resources require the suitable mechanism facilitating the flexible flows of skill and knowledge transfer processes. IPB will actively promote transdisciplinary research and innovation for better impacts on nation's economic advancement and people prosperity.

\section{References}

1. CCAP. Seven Challenges Facing Higher Education. https:/www.forbes.com/sites/ccap/2017/08/29/seve n-challenges-facing-highereducation/\#414a24be3180. (2017)

2. Burger, P. and Kamber, R., Cognitive integration in transdisciplinary science: Knowledge as a key notion. Issues in Interdisciplinary Studies. 21, pp. 43-73. (2003)

3. Payumo, J.G., Arasu, P., Fauzi, A.M., Siregar, I.Z. and Noviana, D., An entrepreneurial, research-based university model focused on intellectual property management for economic development in emerging economies: The case of Bogor Agricultural University, Indonesia. World Patent Information, 36, pp.22-31. (2014). 